\title{
PERBANDINGAN PENGENAAN PBB SEKTOR PERDESAAN \& PERKOTAAN DI PROVINSI DKI JAKARTA , BEKASI, \& DEPOK BERDASARKAN SPPT PBB TAHUN 2014 \& 2015
}

\author{
Fitria Arianty ${ }^{1}$ \\ Thesa Adi Purwanto ${ }^{2}$ \\ ${ }^{1,2}$ Laboratorium Perpajakan, Program Vokasi UI,arianty_fitria@yahoo.com,thesa@vokasi.ui.ac.id
}

\begin{abstract}
Abstrak
Pemungutan Pajak Bumi dan Bangunan Sektor Pedesaan dan Perkotaan yang pengenaannya didasarkan pada Peraturan Daerah masing-masing, dapat berbeda-beda antara satu daerah dengan daerah yang lain. Hal ini disebabkan karena pengenaan Pajak Bumi dan Bangunan Sektor Pedesaan dan Perkotaan tersebut diserahkan kewenangannya kepada Pemerintah Daerah masing-masing. Penelitian ini bertujuan untuk membandingkan kebijakan Pajak Bumi dan Bangunan Sektor Pedesaan dan Perkotaan di provinsi DKI Jakarta, Bekasi, dan Depok, berdasarkan SPPT PBB Tahun 2014 dan Tahun 2015. Dalam menganalisis permasalahan pengenaan PBB Sektor P2 di provinsi DKI Jakarta, Bekasi, dan Depok, informasi yang diperoleh didapatkan dari wawancara fiskus dan observasi lapangan. Kebijakan PBB Sektor P2 di provinsi DKI Jakarta, Bekasi, dan Depok berbeda-beda dari segi tarif pajak, besarnya NJOPTKP, serta penentuan besarnya NJOP. Besarnya NJOP di Provinsi DKI Jakarta lebih tinggi dan lebih beragam dibandingkan dengan NJOP di kota Depok dan Bekasi. Penentuan besarnya NJOP di Provinsi DKI Jakarta juga ditetapkan lebih sering daripada di kota Depok dan Bekasi, yakni setiap satu tahun. Hal ini disebabkan karena nilai tanah dan bangunan di Provinsi DKI Jakarta lebih cepat naik daripada di Depok dan Bekasi.
\end{abstract}

Kata Kunci: $\mathrm{PBB}$ P2, NJOP, Pajak Daerah.

\begin{abstract}
Tax on Land and Building, Rural and Urban Sector based on the regional regulation may vary from one region to another. This is because the imposition authority of tax on land and building, rural and urban sectors were handed over to local governments. This study aimed to compare the land and building, Rural and Urban Sector tax policies in DKI Jakarta, Bekasi, Depok, based on SPPT 2014 and 2015. In analyzing the problems of the imposition tax on land and building, rural and urban sectors in DKI Jakarta, Bekasi, Depok, information obtained from interviews with tax authorities and field observations. The land and building, Rural and Urban Sector tax policies in DKI Jakarta, Bekasi, Depok different in terms of tax rates, determination the amount of NJOPTKP, as well as the amount of NJOP. The amount of NJOP in Jakarta is higher and more diverse than the amount of NJOP in Depok and Bekasi. Determination the amount of NJOP in Jakarta also set more frequently, which every year than in the city of Depok and Bekasi. This is because the value of land and buildings in Jakarta faster rise than in Depok and Bekasi.
\end{abstract}

Keywords: Tax on Land and Building, Rural and Urban Sector, Local Tax.

\section{PENDAHULUAN}

\section{Latar Belakang}

PBB Sektor Perdesaan \& Perkotaan (selanjutnya disingkat menjadi PBB Sektor $\mathrm{P} 2)$ adalah jenis pajak daerah yang baru ditetapkan dengan Undang-undang Nomor 28
Tahun 2009 tentang Pajak Daerah \& Retribusi Daerah. Undang-undang tersebut mulai berlaku pada tanggal 1 Januari 2010, namun untuk PBB Sektor $\mathrm{P} 2$ sepanjang di masing-masing daerah belum dikeluarkan Peraturan Daerah yang mengatur tentang 
pengenaan $\mathrm{PBB}$ Sektor $\mathrm{P} 2$, maka pemungutan PBB tetap menjadi kewenangan Pemerintah Pusat sampai dengan akhir tahun 2013. Mulai 1 Januari 2014 barulah pemungutan PBB Sektor $\mathrm{P} 2$ telah sepenuhnya menjadi wewenang Pemerintah Daerah. Sehubungan dengan hal tersebut, tantangan muncul bagi pemerintah daerah dalam upaya memungut pajak daerah yang telah diserahkan kewenangannya oleh pemerintah pusat. Sebab penerimaan dari sektor $\mathrm{PBB}-\mathrm{P} 2$ yang telah dilimpahkan kepada pemerintah daerah akan lebih optimal apabila pemerintah daerah mampu mengelolanya dengan baik, baik dari segi pemungutan maupun penggunaan anggaran.

Pengalihan pengelolaan Pajak Bumi dan Bangunan Pedesaan dan Perkotaan (PBB P2) dari Pemerintah Pusat kepada Pemerintah Daerah tersebut merupakan suatu tindak lanjut kerja otonomi daerah dan desentralisasi fiskal. Sehubungan dengan hal terebut maka proses pendataan, penilaian, penetapan, pemungutan atau penagihan dan pelayanan $\mathrm{PBB} \mathrm{P}_{2}$ diselenggarakan oleh Kabupaten atau Kota Pemerintah Daerah. Pemungutan PBB Sektor $\mathrm{P} 2$ yang pengenaannya didasarkan pada Peraturan Daerah masing-masing, dapat berbeda-beda antara satu daerah dengan daerah yang lain. Hal ini disebabkan karena pengenaan $\mathrm{PBB}$ Sektor $\mathrm{P} 2$ tersebut diserahkan kewenangannya kepada.

Pemerintah Daerah masing - masing Penentuan besarnya Nilai Jual Objek Pajak (NJOP), Nilai Jual Objek Pajak Tidak Kena Pajak (NJOPTKP), tarif pajak, dan sebagainya sepenuhnya diatur oleh Pemerintah Daerah masing-masing yang dituangkan dalam bentuk Peraturan Daerah.

Tahun 2015 ini pengenaan $\mathrm{PBB}$ Sektor $\mathrm{P} 2$ yang dikenakan berdasarkan Peraturan Daerah masing-masing telah dua tahun berjalan. Terdapat perbedaan penghitungan PBB Sektor P2 antara Tahun 2014 dan Tahun 2015 berdasarkan Surat Pemberitahuan Pajak Terutang (SPPT) PBB yang diterbitkan. Perbedaan tersebut antara lain disebabkan karena adanya perubahan jumlah NJOP dari masing-masing objek pajak di setiap daerah.

Berdasarkan latar belakang tersebut maka perlu ditinjau lebih lanjut bagaimana perbandingan pengenaan $\mathrm{PBB}$ Sektor $\mathrm{P} 2$ di beberapa kota, yaitu Provinsi DKI Jakarta, Bekasi, dan Depok beserta kendala-kendala yang dihadapi oleh Pemerintah Daerah dalam pelaksanaan pemungutan $\mathrm{PBB}$ Sektor $\mathrm{P} 2$ di daerah masing-masing, serta bagaimana upaya yang dilakukanoleh Pemerintah Daerah untuk mengatasi kendala-kendala tersebut.

\section{METODE}

Dalam penelitian ini, data dikumpulkan dari Dinas Pendapatan Daerah (Dispenda) Daerah Khusus Ibukota Jakarta, Dinas Pendapatan Pengelolaan Keuangan dan Aset Kota Depok, dan Dinas Pendapatan Daerah (Dispenda) Kota Bekasi tentangpengenaan Pajak Bumi dan Bangunan Sektor Pedesaan dan Perkotaan. Data yang dikumpulkan berupa data besarnya Nilai Jual Objek Pajak (NJOP), Nilai Jual Objek Pajak Tidak Kena Pajak (NJOPTKP), tarif pajak, dan cara pelunasan pajak. 
Untuk analisis permasalahan dalam pengenaan Pajak Bumi dan Bangunan Sektor Pedesaan dan Perkotaan, informasi yang diperoleh didapatkan dari wawancara fiskus dan observasi lapangan.Database realisasi penerimaan Pajak Bumi dan Bangunan di DKI Jakarta, Kota Bekasi dan Kota Depok akandibandingkan dan dianalisis untuk mendapatkan informasi tentang pelaksanaan kebijakan pengenaan Pajak Bumi dan Bangunan Sektor Pedesaan dan Perkotaan beserta permasalahan yang ditimbulkan. Informasi yang diperoleh akan analisis, sehingga dapat ditarik kesimpulan yang menggambarkan hasil dari analisis tersebut.

\section{HASIL DAN PEMBAHASAN}

\section{Gambaran Umum PBB Sektor Perdesaan \& Perkotaan}

Berdasarkan ketentuan UU No.28 Tahun 2009 tentang Pajak daerah dan Retribusi Daerah Pasal 1 angka 37, Pajak Bumi dan Bangunan Perdesaan dan Perkotaan (selajnjutnya disingkat $\mathrm{PBB}$ sektor $\mathrm{P} 2$ ) adalah pajak atas bumi dan/atau bangunan yang dimiliki, dikuasai, dan/atau dimanfaatkan oleh orang pribadi atau Badan, kecuali kawasan yang digunakan untuk kegiatan usaha perkebunan, perhutanan, dan pertambangan. Selanjutnya pada pasal yang sama angka 38 dan angka 39 disebutkan bahwa yang dimaksud dengan Bumi adalah permukaan bumi yang meliputi tanah dan perairan pedalaman serta laut wilayah kabupaten/kota. Sedangkan pengertian Bangunan adalah konstruksi teknik yang ditanam atau dilekatkan secara tetap pada tanah dan/atau perairan pedalaman dan/atau laut. PBB Sektor $\mathrm{P} 2$ termasuk dalam pajak daerah yang dipungut di tingkat Kabupaten/Kota.

\section{Objek PBB Sektor P2}

Objek Pajak Bumi dan Bangunan Perdesaan dan Perkotaan adalah Bumi dan/atau Bangunan yang dimiliki, dikuasai, dan/atau dimanfaatkan oleh orang pribadi atau Badan, kecuali kawasan yang digunakan untuk kegiatan usaha perkebunan, perhutanan, dan pertambangan.

Termasuk dalam pengertian Bangunan adalah:

a. jalan lingkungan yang terletak dalam satu kompleks bangunan seperti hotel, pabrik, dan emplasemennya, yang merupakan suatu kesatuan dengan kompleks Bangunan tersebut;

b. jalan tol;

c. kolam renang;

d. pagar mewah;

e. tempat olahraga;

f. galangan kapal, dermaga;

g. taman mewah;

h. tempat penampungan/kilang minyak, air dan gas, pipa minyak; dan menara.

Objek Pajak yang tidak dikenakan Pajak Bumi dan Bangunan Perdesaan dan Perkotaan adalah objek pajak yang:

a. digunakan oleh Pemerintah dan Daerah untuk penyelenggaraan pemerintahan;

b. digunakan semata-mata untuk melayani kepentingan umum dibidang ibadah,sosial, 


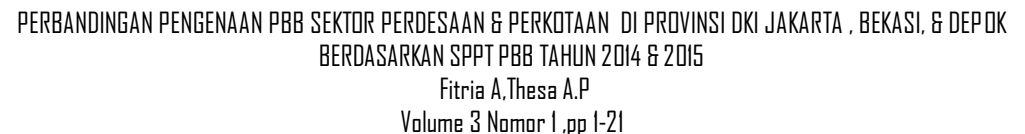

kesehatan, pendidikan dan kebudayaan nasional, yang tidak dimaksudkan untuk memperoleh keuntungan;

c. digunakan untuk kuburan, peninggalan purbakala, atau yang sejenis dengan itu;

d.merupakan hutan lindung, hutan suaka alam, hutan wisata, taman nasional, tanah penggembalaan yang dikuasai oleh desa, dan tanah negara yang belum dibebani suatu hak;

e. digunakan oleh perwakilan diplomatik dan konsulat berdasarkan asas perlakuan timbal balik; dan digunakan oleh badan atau perwakilan lembaga internasional yang ditetapkan dengan Peraturan Menteri Keuangan

\section{Subjek PBB Sektor P2}

Subjek Pajak Bumi dan Bangunan Perdesaan dan Perkotaan adalah orang pribadi atau Badan yang secara nyata mempunyai suatu hak atas Bumi dan/atau memperoleh manfaat atas Bumi, dan/atau memiliki, menguasai, dan/atau memperoleh manfaat atas Bangunan. Wajib Pajak Bumi dan Bangunan Perdesaan dan Perkotaan adalah orang pribadi atau Badan yang secara nyata mempunyai suatu hak atas Bumi dan/atau memperoleh manfaat atas Bumi, dan/atau memiliki, menguasai, dan/atau memperoleh manfaat atas Bangunan.

\section{Dasar Pengenaan Pajak PBB Sektor P2}

Dasar pengenaan Pajak Bumi dan Bangunan Perdesaan dan Perkotaan adalah Nilai Jual Objek Pajak (NJOP). .Besarnya NJOP ditetapkan setiap 3 (tiga) tahun, kecuali untuk objek pajak tertentu dapat ditetapkan setiap tahun sesuai dengan perkembangan wilayahnya. Penetapan besarnya NJOP sebagaimana dilakukan oleh Kepala Daerah.

\section{Tarif PBB Sektor P2}

Tarif Pajak Bumi dan Bangunan Perdesaan dan Perkotaan ditetapkan paling tinggi sebesar 0,3\% (nol koma tiga persen). Tarif Pajak Bumi dan Bangunan Perdesaan dan Perkotaan ditetapkan dengan Peraturan Daerah. Besaran pokok Pajak Bumi dan Bangunan Perdesaan dan Perkotaan yang terutang dihitung dengan cara mengalikan tarif dengan dasar pengenaan pajak setelah dikurangi Nilai Jual Objek Pajak Tidak Kena Pajak Besarnya Nilai Jual Objek Pajak Tidak Kena Pajak ditetapkan paling rendah sebesar Rp10.000.000,00 (sepuluh juta rupiah) untuk setiap Wajib Pajak.Nilai Jual Objek Pajak Tidak Kena Pajak ditetapkan dengan Peraturan Daerah.

\section{Saat Terutang Pajak PBB Sektor P2}

Tahun Pajak adalah jangka waktu 1 (satu) tahun kalender. Saat yang menentukan pajak yang terutang adalah menurut keadaan objek pajak pada tanggal 1 Januari. Tempat pajak yang terutang adalah di wilayah daerah yang meliputi letak objek pajak.

\section{Pendataan Objek Pajak PBB Sektor P2}

Pendataan dilakukan dengan menggunakan Surat Pemberitahuan Objek Pajak (SPOP). SPOP harus diisi dengan jelas, benar, dan lengkap serta ditandatangani dan disampaikan 
kepada Kepala Daerah yang wilayah kerjanya meliputi letak objek pajak, selambatlambatnya 30 (tiga puluh) hari kerja setelah tanggal diterimanya SPOP oleh Subjek Pajak.

Berdasarkan SPOP, Kepala Daerah menerbitkan Surat Pemberitahuan Pajak Terutang (SPPT). Kepala Daerah dapat mengeluarkan Surat Ketetapan Pajak Daerah (SKPD) dalam hal-hal sebagai berikut:

a. SPOP tidak disampaikan dan setelah Wajib Pajak ditegur secara tertulis oleh Kepala Daerah sebagaimana ditentukan dalam Surat Teguran;

b. Berdasarkan hasil pemeriksaan atau keterangan lain ternyata jumlah pajak yang terutang lebih besar dari jumlah pajak yang dihitung berdasarkan SPOP yang disampaikan oleh Wajib Pajak.

\section{PBB Sektor P2 Provinsi DKI Jakarta}

Pengenaan PBB Sektor $\mathrm{P} 2$ di Provinsi DKI Jakarta mengacu pada peraturan-peraturan sebagai berikut :

a. UU RI No 28 Tahun 2009 tentang Pajak Daerah dan Retribusi Daerah

b. Perda No 6 Tahun 2010 tentang Ketentuan Umum Pajak Daerah

c. Perda No 16 Tahun 2011 Tentang Pajak Bumi dan Bangunan (berlaku mulai tanggal 1-1-2013)

d. Peraturan Gubernur No 175 Tahun 2013 Tentang Klasifikasi dan Penetapan Nilai Jual Objek Pajak dan Dasar Pengenaan PBB Pedesaan dan Perkotaan

e. Peraturan Gubernur No.263 Tahun 2014 Tentang Klasifikasi dan Penetapan Nilai Jual Objek Pajak dan Dasar Pengenaan PBB

Pedesaan dan Perkotaan

\section{Objek Pajak \& Subjek Pajak}

Objek PBB Sektor P2 Provinsi DKI Jakarta adalah Bumi dan/atau Bangunan yang dimiliki, dikuasai, dan/atau dimanfaatkan oleh orang pribadi atau Badan, kecuali kawasan yang digunakan untuk kegiatan usaha perkebunan, perhutanan, dan pertambangan.

Termasuk dalam pengertian Bangunan adalah:

a. jalan lingkungan yang terletak dalam satu kompleks bangunan seperti hotel, pabrik dan emplasemennya, yang merupakan suatu kesatuan dengan kompleks bangunan tersebut;

b. jalan tol;

c. kolam renang;

d. pagar mewah;

e. tempat olahraga;

f. galangan kapal, dermaga;

g. taman mewah;

h. tempat penampungan/kilang minyak, air dan gas, pipa minyak; dan

i. menara.

j. rumah susun.

k. apartemen strata title.

Ketentuan lebih lanjut mengenai klasifikasi objek pajak diatur dengan Peraturan Gubernur DKI Jakarta. Adapun Objek Pajak yang tidak dikenakan Pajak adalah objek pajak yang: 
a. digunakan oleh Pemerintah Daerah untuk penyelenggaraan pemerintahan;

b. digunakan semata-mata untuk melayani kepentingan umum di bidang ibadah, sosial, kesehatan, pendidikan, dan kebudayaan nasional, yang tidak dimaksudkan untuk memperoleh keuntungan;

c. digunakan untuk kuburan, peninggalan purbakala, atau yang sejenis dengan itu;

d. merupakan cagar budaya yang tidak dimanfaatkan sebagai tempat hunian/tempat tinggal, dan kegiatan usaha atau sejenisnya, tidak dimaksudkan untuk memperoleh keuntungan ;

e. merupakan Ruang Terbuka Hijau (Kawasan hijau lindung dan hijau binaan), hutan lindung, hutan suaka alam, hutan wisata, taman nasional, dan tanah negara yang belum dibebani suatu hak;

f. digunakan oleh perwakilan diplomatik dan konsulat berdasarkan asas perlakuan timbal balik; dan

g. digunakan oleh badan atau perwakilan lembaga internasional yang ditetapkan dengan Peraturan Menteri Keuangan.

Yang menjadi Subjek Pajak PBB Sektor P2 Provinsi DKI Jakarta adalah orang pribadi atau Badan yang secara nyata mempunyai suatu hak atas Bumi dan/atau memperoleh manfaat atas Bumi, dan/atau memiliki, menguasai, dan/atau memperoleh manfaat atas Bangunan. Subjek Pajak yang dikenakan kewajiban membayar pajak menjadi Wajib Pajak menurut Peraturan Daerah ini.
Dalam hal atas suatu objek pajak belum jelas diketahui wajib pajaknya, Kepala Dinas Pelayanan Pajak atas nama Gubernur dapat menetapkan subjek pajak sebagai Wajib Pajak. Subjek pajak yang ditetapkan sebagai Wajib Pajak dapat memberikan keterangan secara tertulis kepada Kepala Dinas Pelayanan Pajak bahwa ia bukan wajib pajak terhadap objek pajak dimaksud. Bila keterangan yang diajukan oleh wajib pajak tersebut disetujui, maka Kepala Dinas Pelayanan Pajak membatalkan penetapan sebagai wajib pajak dalam jangka waktu 1 (satu) bulan sejak diterimanya surat keterangan dimaksud. Sebaliknya, bila keterangan yang diajukan itu tidak disetujui, maka Kepala Dinas Pelayanan Pajak mengeluarkan surat keputusan penolakan dengan disertai alasan-alasannya. Apabila setelah jangka waktu satu bulan sejak tanggal diterimanya keterangan Kepala Dinas Pelayanan Pajak tidak memberikan keputusan, maka keterangan yang diajukan itu dianggap disetujui.

\section{Tarif Pajak, Dasar Pengenaan Pajak, Nilai Jual Objek Pajak Tidak kena Pajak \& Cara Menghitung Pajak}

Tarif Pajak Bumi dan Bangunan Sektor P2 Provinsi DKI Jakarta ditetapkan sebagai berikut:

a. Tarif 0,01\% (nol koma nol satu persen) untuk Nilai Jual Objek Pajak Tanah dan/atau Bangunan kurang dari Rp.200.000.000,- (dua ratus juta rupiah);

b. Tarif $0,1 \%$ (nol koma satu persen) untuk Nilai Jual Objek Pajak Tanah dan/atau 
Bangunan Rp.200.000.000,- (dua ratus juta rupiah) sampai dengan kurang dari Rp.2.000.000.000. (dua miliar rupiah);

c. Tarif $0,2 \%$ (nol koma dua persen) untuk Nilai Jual Objek Pajak Tanah dan/atau Bangunan Rp.2.000.000.000.- (dua miliar rupiah) sampai dengan kurang dari Rp.10.000.000.000.- (sepuluh miliar rupiah);

d. Tarif 0,3\% (nol koma tiga persen) untuk Nilai Jual Objek Pajak Tanah dan/atau Bangunan Rp.10.000.000.000,- (sepuluh miliar rupiah) atau lebih.

Untuk lebih jelas, tarif dan DPP PBB Sektor P2 Provinsi DKI Jakarta dapat dilihat dalam tabel berikut ini : mulai berlaku pada tanggal 30 Desember 2014. Besarnya pokok PBB Sektor P2 yang terhutang dihitung dengan cara mengalikan tarif dengan dasar pengenaan pajak setelah dikurangi Nilai Jual Objek Pajak Tidak Kena Pajak Besarnya Nilai Jual Objek Pajak Tidak Kena Pajak (NJOPTKP) ditetapkan sebesar Rp.15.000.000,- (lima belas juta rupiah) untuk setiap Wajib Pajak.

\section{Masa,Saat,dan Tempat Pajak Terutang}

Tahun Pajak adalah jangka waktu 1 (satu) tahun kalender. Saat yang menentukan pajak terutang adalah menurut keadaan objek pajak pada tanggal 1 Januari. Tempat Terutang Pajak Bumi dan Bangunan Perdesaan dan Perkotaan adalah di Wilayah Provinsi Daerah

Tabel 1

Tarif PBB Sektor P2 DKI Jakarta

\begin{tabular}{|c|l|c|}
\hline No & \multicolumn{1}{|c|}{ NJOP Bumi \& Bangunan } & Tarif \\
\hline 1 & $<$ Rp.200.000.000 & $0,01 \%$ \\
\hline 2 & Rp.200.000.000 s.d < Rp. 2.000.000.000 & $0,1 \%$ \\
\hline 3 & Rp. 2.000.000.000 s.d < Rp. 10.000.000.000 & $0,2 \%$ \\
\hline 4 & $\geq$ Rp. 10.000.000.000 & $0,3 \%$ \\
\hline
\end{tabular}

Sumber : Perda No.16 Tahun 2011, diolah kembali oleh penulis

Dasar pengenaan Pajak Bumi dan Bangunan Perdesaan dan Perkotaan adalah Nilai Jual Objek Pajak (NJOP). Besarnya NJOP ditetapkan setiap 1 (satu) tahun. Penetapan besarnya NJOP ditetapkan dengan Peraturan Gubernur (Pergub). Adapun Pergub DKI Jakarta yang mengatur mengenai penetapan besarnya NJOP adalah Peraturan Gubernur No 175 Tahun 2013, yang berlaku mulai 1 Januari 2013 sampai dengan 29 Desember 2014. Pergub tersebut kemudian diganti dengan Pergub No.263 Tahun 2014, yang
Pelaksanaan Pengenaan PBB Sektor P2 Provinsi DKI Jakarta

Perda No.16 Tahun 2011 tentang pelaksanaan PBB Sektor $\mathrm{P} 2$ mulai diberlakukan pada tanggal 1 Januari 2013. Oleh karena itu mulai tahun pajak 2013, pengenaan PBB Sektor P2 Provinsi DKI Jakarta telah sepenuhnya mengacu pada ketentuan yang diatur dalam Perda tersebut. Berikut adalah pembahasan tentang pelaksanaan pengenaan PBB Sektor $\mathrm{P}_{2}$ Provinsi DKI Jakarta yang meliputi Tahun Pajak 2014 dan 2015 bagi Wajib Pajak 
yangdikenakan $\mathrm{PBB}$ dengan tarif $0,01 \%, 0,1 \%$, $0,2 \%$, dan $0,3 \%$.

Wajib Pajak PBB P2 yang dikenakan Tarif $0,01 \%$

Nama WP : Haerudin

Alamat : Jl.Asirot Dalam

RT.002 RW 01

Jakarta Barat

Tahun pajak : 2014

\begin{tabular}{|c|c|c|c|c|}
\hline $\begin{array}{l}\text { Objek } \\
\text { Pajak }\end{array}$ & $\begin{array}{l}\text { Luas } \\
\left(\mathbf{M}^{2}\right)\end{array}$ & Kls & $\begin{array}{c}\text { NJOP } \\
\text { Per M }^{2} \\
(\text { Rp) } \\
\text { Ribuan }\end{array}$ & $\begin{array}{c}\text { Total } \\
\text { NJOP } \\
(\mathbf{R p}) \\
\text { Ribua } \\
\text { n }\end{array}$ \\
\hline Bumi & 30 & $\begin{array}{l}\text { O6 } \\
\text { O }\end{array}$ & 1.722 & 51.660 \\
\hline Bangunan & 30 & $\begin{array}{l}\text { O2 } \\
6\end{array}$ & 505 & 15.150 \\
\hline
\end{tabular}

NJOP PBB $=$ Rp. 66.810.000

NJOPTKP $=$ Rp. 15.000 .000

NJOP Kena Pjk $=\quad$ Rp. 51.810 .000

PBB terutang $=0,01 \% \times$ Rp. 51.810 .000

$$
=\text { Rp. } 5.181
$$

Tahun Pajak : 2015

\begin{tabular}{|l|l|c|c|c|}
\hline $\begin{array}{c}\text { Objek } \\
\text { Pajak }\end{array}$ & $\begin{array}{c}\text { Luas } \\
\left(\mathbf{M}^{\mathbf{2}}\right)\end{array}$ & Kls & $\begin{array}{c}\text { NJOP } \\
\text { Per M } \\
\text { (Rp) } \\
\text { Ribuan }\end{array}$ & $\begin{array}{c}\text { Total } \\
\text { NJOP } \\
\text { (Rp) } \\
\text { Ribua } \\
\mathbf{n}\end{array}$ \\
\hline Bumi & 30 & 156 & 1.722 & 51.660 \\
\hline Bangunan & 30 & 046 & 595 & 17.850 \\
\hline
\end{tabular}

NJOP PBB $=$ Rp. 69.510.000

NJOPTKP $=\underline{\text { Rp. } 15.000 .000}$

NJOP Kena Pjk $=\quad$ Rp. 54.510.000

PBB terutang $=0,01 \% \times$ Rp. 54.510 .000

$$
=\text { Rp. } 5.451
$$

Wajib Pajak PBB P2 yang dikenakan Tarif $0,1 \%$

Nama WP : Hetty Suharwati

Alamat $\quad$ : Jl.Asirot Dalam
RT.012 RW 001

Jakarta Barat

Tahun pajak : 2014

\begin{tabular}{|l|l|l|l|l|}
\hline $\begin{array}{c}\text { Objek } \\
\text { Pajak }\end{array}$ & $\begin{array}{c}\text { Luas } \\
\left(\mathbf{M}^{\mathbf{2}}\right)\end{array}$ & Kls & $\begin{array}{c}\text { NJOP } \\
\mathbf{P e r}^{\mathbf{2}} \\
(\mathbf{R p}) \\
\text { Ribuan }\end{array}$ & $\begin{array}{c}\text { Total } \\
\text { NJOP } \\
(\mathbf{R p}) \\
\text { Ribuan }\end{array}$ \\
\hline Bumi & 180 & 060 & 1.722 & 309.960 \\
\hline Bangunan & 130 & 021 & 1.200 & 156.000 \\
\hline
\end{tabular}

$$
\begin{aligned}
& \text { NJOP PBB }=\text { Rp. } 465.960 .000 \\
& \text { NJOPTKP }=\text { Rp. } 15.000 .000 \\
& \text { NJOP Kena Pjk }=\quad \text { Rp. } 450.960 .000 \\
& \text { PBB terutang }=0,1 \% \times \text { Rp. } 450.960 .000 \\
& =\text { Rp. } 450.960
\end{aligned}
$$

Tahun pajak : 2015

\begin{tabular}{|l|l|l|c|c|}
\hline $\begin{array}{c}\text { Objek } \\
\text { Pajak }\end{array}$ & $\begin{array}{c}\text { Luas } \\
\left.\mathbf{( M}^{\mathbf{2}}\right)\end{array}$ & Kls & $\begin{array}{c}\text { NJOP } \\
\text { Per M } \\
\text { (Rp) } \\
\text { Ribuan }\end{array}$ & $\begin{array}{c}\text { Total } \\
\text { NJOP } \\
\text { (Rp) } \\
\text { Ribuan }\end{array}$ \\
\hline Bumi & 180 & 156 & 1.722 & 309.960 \\
\hline Bangunan & 130 & 041 & 1.516 & 197.080 \\
\hline
\end{tabular}

$$
\begin{array}{lll}
\text { NJOP PBB } & = & \text { Rp. } 507.040 .000 \\
\text { NJOPTKP } & = & \text { Rp. } 15.000 .000 \\
\text { NJOP Kena Pjk } & & \text { Rp. } 492.040 .000
\end{array}
$$

PBB terutang $=0,1 \%$ x Rp. 492.040.000

$$
=\text { Rp. } 492.040
$$

Wajib Pajak PBB P2 yang dikenakan Tarif $0,2 \%$

Nama WP : Yusuf Ibrahim

Alamat : Jl.Keuangan III No.81

Cilandak Jaksel

Tahun pajak : 2014

\begin{tabular}{|l|c|c|c|c|}
\hline $\begin{array}{c}\text { Objek } \\
\text { Pajak }\end{array}$ & $\begin{array}{c}\text { Luas } \\
\left(\mathbf{M}^{\mathbf{2}}\right)\end{array}$ & Kls & $\begin{array}{c}\text { NJOP } \\
\text { Per } \mathbf{M}^{\mathbf{2}} \\
(\mathbf{R p}) \\
\text { Ribuan }\end{array}$ & $\begin{array}{c}\text { Total } \\
\text { NJOP } \\
(\mathbf{R p}) \\
\text { Ribuan }\end{array}$ \\
\hline Bumi & 336 & 045 & 5.625 & $\begin{array}{c}1.890 .00 \\
0\end{array}$ \\
\hline Bangunan & 188 & 026 & 1.516 & 285.008 \\
\hline
\end{tabular}

$$
\begin{aligned}
& \text { NJOP PBB }=\text { Rp. 2.175.008.000 } \\
& \text { NJOPTKP }=\underline{\text { Rp. } 15.000 .000} \\
& \text { NJOP Kena Pjk }
\end{aligned}
$$


PBB terutang $=0,2 \% \times$ Rp.2.160.008.000 $=$ Rp. 4.320 .000

Tahun pajak : 2015

\begin{tabular}{|l|c|c|c|c|}
\hline $\begin{array}{c}\text { Objek } \\
\text { Pajak }\end{array}$ & $\begin{array}{c}\text { Luas } \\
\left(\mathbf{M}^{\mathbf{2}}\right)\end{array}$ & $\begin{array}{c}\text { Kl } \\
\mathbf{s}\end{array}$ & $\begin{array}{c}\text { NJOP } \\
\text { Per M } \\
(\mathbf{R p}) \\
\text { Ribuan }\end{array}$ & $\begin{array}{c}\text { Total } \\
\text { NJOP } \\
(\mathbf{R p}) \\
\text { Ribuan }\end{array}$ \\
\hline Bumi & 336 & $\begin{array}{c}13 \\
1\end{array}$ & 7.455 & 2.504 .880 \\
\hline Bangunan & 188 & $\begin{array}{c}04 \\
0\end{array}$ & 1.833 & 344.604 \\
\hline
\end{tabular}

NJOP PBB $=$ Rp. 2.849.484.000

NJOPTKP $=$ Rp. 15.000 .000

NJOP Kena Pjk $=$ Rp. 2.834.484.000

$\mathrm{PBB}$ terutang $=0,2 \% \times$ Rp.2.834.484.000 $=$

Rp. 5.668.968

Dari data-data tersebut di atas dapat dilihat bahwa pelaksanaan pengenaan PBB Sektor P2 di provinsi DKI Jakarta telah dijalankan sesuai dengan ketentuan UU No.28 Tahun 2009 tentang Pajak Daerah dan Retribusi Daerah. Hal ini dapat dilihat dari ketentuan mengenai objek pajak, subjek pajak, tarif pajak, dasar pengenaan pajak, serta besarnya NJOPTKP dan cara penghitungan pajak terutang.

Tarif Pajak untuk PBB Sektor P2 di Provinsi DKI Jakarta ditetapkan mulai dari 0,01\% sampai dengan $0,3 \%$. Walaupun dibuat dalam empat lapisan NJOP dengan empat jenis tarif, namun hal ini tidak melanggar ketentuan dalam UU No.28 Tahun 2009 Pasal 88, yang menyebutkan bahwa Tarif Pajak Bumi dan Bangunan Perdesaan dan Perkotaan ditetapkan paling tinggi sebesar 0,3\% (nol koma tiga persen). Perda No.16 Tahun 2011 menetapkan tarif tertinggi sebesar 0,3\% yang dikenakan atas objek pajak dengan NJOP bumi \& bangunan sebesar Rp.10.000.000.000,(sepuluh milyar) ke atas.

Ketentuan mengenai besarnya NJOPTKP dalam pengenaan PBB Sektor $\mathrm{P} 2$ di Provinsi DKI Jakarta juga sudah sesuai dengan ketentuan dalam UU No.28 Tahun 2009 Pasal 77 , yang menyebutkan bahwa besarnya NJOPTKP ditetapkan paling rendah sebesar
Rp.10.000.000,- (sepuluh juta rupiah) untuk setiap Wajib Pajak. Perda No.16 Tahun 2011 menetapkan besarnya NJOPTKP di wilayah DKI Jakarta sebesar Rp.15.000.000,- (lima belas juta rupiah) untuk setiap Wajib Pajak. Menurut ketentuan dalam UU No.28 Tahun 2009 Pasal 79 ayat 1 \& 2 Dasar pengenaan Pajak Bumi dan Bangunan Perdesaan dan Perkotaan adalah Nilai Jual Objek Pajak (NJOP). Besarnya NJOP ditetapkan setiap 3 (tiga) tahun, kecuali untuk objek pajak tertentu dapat ditetapkan setiap tahun sesuai dengan perkembangan wilayahnya. Ketentuan yang berbeda diatur dalam Perda No.16 Tahun 2011 Pasal 7 ayat 2 yang menyebutkan bahwa besarnya NJOP ditetapkan setiap 1 tahun. Dalam pelaksanaan pengenaan $\mathrm{PBB}$ Sektor $\mathrm{P} 2$ di provinsi $\mathrm{DKI}$ Jakarta, besarnya NJOP yang ditetapkan ssampai saat ini telah mengalami tiga kali perubahan. Terhitung mulai tanggal 1 Januari 2013 sampai dengan 30 Desember 2013, besarnya NJOP yang ditetapkan mengacu pada ketentuan dalam Pergub DKI Jakarta No. No 200 Tahun 2012 tentang Klasifikasi dan Penetapan Nilai Jual Objek Pajak dan Dasar Pengenaan PBB Pedesaan dan Perkotaan. Ketentuan tersebut kemudian diubah dengan Pergub DKI Jakarta No.175 Tahun 2013, yang berlaku mulai 1 Januari 2014 sampai dengan 29 Desember 2014. Ketentuan tersebut kemudian diubah kembali dengan Pergub DKI Jakarta No.263 Tahun 2014, yang mulai berlaku pada tanggal 30 Desember 2014.

Klasifikasi NJOP berdasarkan Lapmiran I \& II Pergub No.175 Tahun 2013 terdiri dari 100 kelas klasifikasi untuk Bumi dan 40 kelas Bangunan. NJOP Bumi dengan nilai tertinggi per meter persegi > Rp.67.390.000,- s/d Rp.69.700.000,-, dengan nilai konversi Rp.68.545.000,-. Sedangkan untuk klasifikasi terendah ada di kelas 100 dengan nilai NJOP $<$ Rp.170,- per meter persegi (dikonversi menjadi Rp.140,-). NJOP Bangunan dengan nilai tertinggi ada di kelas 001 dengan nilai bangunan per meter persegi > Rp.14.700.000,- s/d Rp.15.800.000,- 
(dikonversi menjadi Rp.15.250.000,-). Sedangkan nilai Bangunan terendah ada di kelas 40 dengan nilai $\leq$ Rp.52.000,(dikonversi menjadi Rp.50.000,-).

Klasifikasi NJOP berdasarkan Lampiran I \& II Pergub No.263 Tahun 2014 terdiri dari 190 kelas klasifikasi untuk Bumi dan 60 kelas Bangunan. NJOP Bumi dengan nilai tertinggi per meter persegi > Rp.149.855.000 s/d Rp.152.185.000 (dikonversi menjadi Rp.151.020.000,-). Sedangkan nilai terendah ada di kelas 190 dengan nilai $\leq$ Rp.1.050,(dikonversi menjadi Rp.910,-). menjadi Rp.50.000,-), sedangkan nilai tertinggi ada di kelas 60 dengan nilai > Rp.48.300.000,- $\quad$ s/d Rp.50.450.000,(dikonversi menjadi Rp.49.375.000,). Untuk lebih jelas, perbedaan antara Klasifikasi NJOP Bumi \& Bangunan berdasarkan Pergub No.175 Tahun 2013 dengan Pergub No.263 Tahun 2014 dapat dilihat dalam tabel 2 .

Berdasarkan table 3 perbedaan klasifikasi NJOP di atas, maka jumlah PBB terutang untuk Tahun Pajak 2014 dan Tahun Pajak 2015 menjadi berbeda, padahal objek pajak tidak mengalami perubahan luas tanah maupun bangunan.

Tabel 2. Perbedaan Klasifikasi NJOP Bumi \& Bangunan

\begin{tabular}{|l|l|l|}
\hline \multicolumn{1}{|c|}{ Uraian } & \multicolumn{1}{|c|}{$\begin{array}{c}\text { Pergub No.175 } \\
\text { Tahun 2013 }\end{array}$} & \multicolumn{1}{|c|}{$\begin{array}{c}\text { Pergub No.263 } \\
\text { Tahun 2014 }\end{array}$} \\
\hline $\begin{array}{l}\text { Jumlah kelas klasifikasi } \\
\text { Bumi }\end{array}$ & 100 & 190 \\
\hline $\begin{array}{l}\text { Jumlah kelas klasifikasi } \\
\text { Bangunan }\end{array}$ & 40 & 60 \\
\hline NJOP bumi terendah & Rp.140 & Rp.910 \\
\hline NJOP bumi tertinggi & Rp.68.585.000 & Rp.151.020.000 \\
\hline $\begin{array}{l}\text { NJOP bangunan } \\
\text { terendah }\end{array}$ & Rp.50.000 & Rp.50.000 \\
\hline $\begin{array}{l}\text { NJOP bangunan } \\
\text { tertinggi }\end{array}$ & Rp.15.250.000 & Rp.49.375.000 \\
\hline Sumbr & Pampiran & \\
\hline
\end{tabular}

Sumber : Lampiran I \& II Pergub DKI Jakarta No.175/2013 \& Pergub DKI

Jakarta No.263/2014, diolah kembali oleh penulis

Tabel 3

Perbedaan Jumlah PBB terutang Tahun Pajak 2014 \& 2015 Wajib Pajak yang dikenakan Tarif 0,01\%

\begin{tabular}{|l|c|c|}
\hline \multicolumn{1}{|c|}{ Uraian } & $\begin{array}{c}\text { SPPT PBB Tahun } \\
\mathbf{2 0 1 4} \\
(\mathbf{R p} .)\end{array}$ & $\begin{array}{c}\text { SPPT PBB Tahun } \\
\mathbf{2 0 1 5} \\
(\mathbf{R p} .)\end{array}$ \\
\hline NJOP Bumi & 51.660 .000 & 51.660 .000 \\
\hline NJOP Bangunan & 15.150 .000 & 17.850 .000 \\
\hline $\begin{array}{l}\text { NJOP sebagai DPP PBB } \\
\text { P2 }\end{array}$ & 66.810 .000 & 69.510 .000 \\
\hline NJOPTKP & 15.000 .000 & 15.000 .000 \\
\hline $\begin{array}{l}\text { NJOP untuk penghitungan } \\
\text { PBB P2 }\end{array}$ & 51.810 .000 & 54.510 .000 \\
\hline PBB P2 terutang (0.01\%) & 5.181 & 5.451 \\
\hline
\end{tabular}

Sumber : SPPT PBB Tahun $2014 \& 2015$ diolah kembali oleh penulis

NJOP Bangunan nilai terendah ada di kelas 001 dengan nilai $\leq$ Rp.60.000,- (dikonversi
Hal ini dapat dilihat dari data-data yang ditemukan dalam SPPT PBB untuk Wajib 
Pajak yang sama yang diterbitkan pada Tahun 2014 dan Tahun 2015. Dari tabel 3 dapat dilihat bahwa terjadi kenaikan jumlah PBB terutang sebesar Rp.270,-atau sekitar $5,2 \%$. Kenaikan ini disebabkan karena adanya kenaikan NJOP Bangunan, yang pada tahun 2014 berada di kelas 26 dengan nilai NJOP per meter persegi sebesar Rp.505.000,- , pada tahun 2015 naik menjadi Rp. 595.000,- per meter persegi dan berada di kelas 46 . Selanjutnya akan penulis tampilkan penghitungan PBB terutang untuk Wajib Pajak yang dikenakan tarif $0,1 \%$ untuk tahun 2014 dan 2015 :
Dari tabel 4 bagi Wajib Pajak yang dikenakan tarif $0,1 \%$ juga mengalami kenaikan jumlah PBB terutang yakni sebesar Rp.41.080,- atau sekitar 9,1\%. Kenaikan ini disebabkan karena nilai NJOP bangunan mengalami kenaikan. Pada tahun 2014 nilai bangunan berada di kelas 021 dengan NJOP sebesar Rp. 1.200.000,- per meter persegi. Pada tahun 2015, nilai bangunan meningkat menjadi Rp.1.516.000,- per meter persegi dan berada pada kelas 041 .

Tabel 4

Perbedaan Jumlah PBB terutang Tahun Pajak 2014 \& 2015 Wajib Pajak yang dikenakan Tarif $0,1 \%$

\begin{tabular}{|l|c|c|}
\hline \multicolumn{1}{|c|}{ Uraian } & $\begin{array}{c}\text { SPPT PBB } \\
\text { Tahun 2014 } \\
\text { (Rp.) }\end{array}$ & $\begin{array}{c}\text { SPPT PBB } \\
\text { Tahun 2015 } \\
\text { (Rp.) }\end{array}$ \\
\hline NJOP Bumi & 309.960 .000 & 309.960 .000 \\
\hline NJOP Bangunan & 156.000 .000 & 197.080 .000 \\
\hline NJOP sebagai DPP PBB P2 & 465.960 .000 & 507.040 .000 \\
\hline NJOPTKP & 15.000 .000 & 15.000 .000 \\
\hline $\begin{array}{l}\text { NJOP untuk penghitungan } \\
\text { PBB P2 }\end{array}$ & 450.960 .000 & 492.040 .000 \\
\hline PBB P2 terutang (O.1\%) & 450.960 & 492.040 \\
\hline
\end{tabular}

Sumber : SPPT PBB Tahun 2014 \& 2015 diolah kembali oleh penulis

Tabel 5

Perbedaan Jumlah PBB terutang Tahun Pajak 2014 \& 2015 Wajib Pajak yang dikenakan Tarif $0,2 \%$

\begin{tabular}{|l|c|c|}
\hline \multicolumn{1}{|c|}{ Uraian } & $\begin{array}{c}\text { SPPT PBB } \\
\text { Tahun 2014 } \\
(\mathbf{R p .})\end{array}$ & $\begin{array}{c}\text { SPPT PBB } \\
\text { Tahun 2015 } \\
(\mathbf{R p .})\end{array}$ \\
\hline NJOP Bumi & 1.890 .000 .000 & 2.504 .880 .000 \\
\hline NJOP Bangunan & 285.008 .000 & 344.604 .000 \\
\hline NJOP sebagai DPP PBB P2 & 2.175 .008 .000 & 2.849 .484 .000 \\
\hline NJOPTKP & 15.000 .000 & 15.000 .000 \\
\hline $\begin{array}{l}\text { NJOP untuk penghitungan } \\
\text { PBB P2 }\end{array}$ & 2.160 .008 .000 & 2.834 .484 .000 \\
\hline PBB P2 terutang (O.1\%) & 4.320 .016 & 5.668 .968 \\
\hline
\end{tabular}

Sumber : SPPT PBB Tahun 2014 \& 2015 diolah kembali oleh penulis 


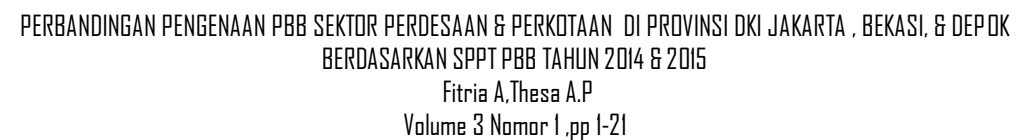

Selanjutnya dapat dilihat pada tabel berikut ini perbedaan jumlah PBB terutang tahun 2014 dan 2015 bagi Wajib Pajak yang dikenakan tarif $0,2 \%$ :

Dari tabel 5 dapat dilihat bahwa jumlah PBB terutang tahun 2015 mengalami peningkatan sebesar Rp.1.348.952,- atau sekitar 31\% dari jumlah PBB terutang tahun sebelumnya. Kenaikan ini disebabkan karena peningkatan NJOP Bumi maupun Bangunan. Pada tahun 2014, nilai bumi berada di kelas 045 dengan NJOP sebesar Rp.5.625.000,- per meter persegi. Nilai bangunan berada di kelas 026 dengan NJOP sebesar Rp. 1.516,000,- per meter persegi. Pada tahun 2015 nilai bumi naik menjadi Rp.7.455.000,- per meter persegi (kelas 131), sementara nilai bangunan berada di kelas 040 dengan NJOP sebesar Rp.1.833.000,- per meter persegi.

Dari data-data tersebut di atas dapat dilihat bahwa kenaikan jumlah PBB terutang tertinggi terjadi pada Wajib Pajak yang dikenakan $\mathrm{PBB}$ dengan tarif $0,2 \%$ yakni sebesar 31\%., disusul kemudian oleh Wajib Pajak yang dikenakan tarif $0,1 \%$ dengan prosentase kenaikan sebesar 9,1\%. Kenaikan terendah terjadi pada Wajib Pajak yang dikenakan tarif terendah pula, yaitu 0,01\%. Prosentase kenaikan jumlah PBB terutang sebesar 5,2\%. Dapat dikatakan bahwa semakin tinggi tarif PBB yang dikenakan, semakin tinggi pula kenaikan jumlah PBB terutang yang harus dibayar oleh Wajib Pajak pada tahun 2015.

Kenaikan NJOP di Provinsi DKI Jakarta ini dipicu oleh beberapa hal, yang salah satunya adalah untuk meningkatkan target penerimaan $\mathrm{PBB}$ Sektor P2.Selain itu kenaikan NJOP ini dilakukan untuk menyesuaikan kenaikan harga tanah dan bangunan di Jakarta yang selalu berubah setiap tahunnya. Sejak Tahun 2010 saat PBB Sektor $\mathrm{P} 2$ masih dipegang oleh Pemerintah Pusat, NJOP belum pernah disesuaikan, sedangkan kondisi pasar tanah dan harga bangun terus berubah. (Hasil wawancara dengan Kepala Dinas Pajak Pemprov DKI, Iwan Setiawandi sebagaimana dimuat oleh Agus Setiawan dalam Detik Finance)

Tingkat kenaikan NJOP di DKI Jakarta bervariasi, tergantung nilai dari objek pajak, yang salah satunya ditentukan oleh dimana objek pajak tersebut berada. Dapat terlihat dari beberapa angka kenaikan pada beberapa wilayah di Jakarta, seperti Kecamatan Jagakarsa (139,5\%), Kebayoran Baru (105,2\%), Kebayoran Lama (84\%), Pasar Minggu (102\%), Kec Pesanggrahan (107\%), Kec Cakung dan Ciracas masing-masing (55\%) dan (76\%). Selain itu, Kec Gambir (136\%), Kec Senen (77\%) dan Tanah Abang (97\%). Kec Kalideres naik (117\%) dan Grogol Petamburan (80\%). Kec Kelapa Gading naik (103\%), Pademangan naik (128\%) dan Tanjung Priok (103\%) (Data diambil dari Lembaga Kajian Hak Asasi \& Demokrasi, diunggah pada tanggal 19 Januari 2015)

\section{PBB Sektor P2 Kota Depok}

Yang menjadi dasar hukum pengenaan PBB Sektor P2 Kota Depok adalah sebagai berikut : Undang-undang Nomor 28 Tahun 2009 tentangPajak Daerah dan Retribusi Daerah; Peraturan Daerah Kota Depok Nomor 07 


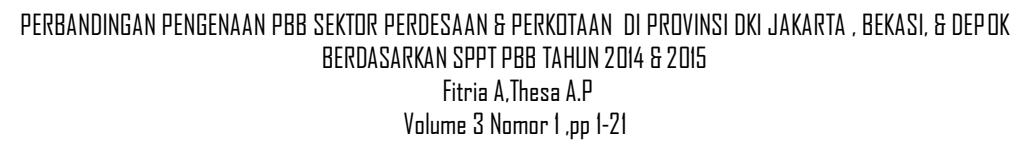

Tahun 2010 tentang Pajak Daerah.dan Peraturan Walikota Depok Nomor 45 Tahun 2011 tentang tata cara pemungutan Pajak Bumi dan Bangunan Perdesaan dan Perkotaan di Kota Depok sebagaimana telah diubah terakhir dengan Peraturan Walikota Depok Nomor 46 Tahun 2013

\section{Objek Pajak \& Subjek Pajak}

Yang menjadi Objek Pajak PBB Sektor P2 di Kota Depok sesuai dengan Peraturan Walikota DepokNomor 46 Tahun 2013 Pasal 1 angka 10 adalah :

Objek Pajak Bumi dan Bangunan Perdesaan dan Perkotaan, yang selanjutnya disebut Objek Pajak adalah Bumi dan/atau Bangunan yang dimiliki, dikuasai, dan/atau dimanfaatkan oleh orang pribadi atau badan, kecuali kawasan yang digunakan untuk kegiatan usaha perkebunan, perhutanan dan pertambangan.

Sedangkan yang Bukan Objek Pajak PBB Sektor $\mathrm{P} 2$ di Kota Depok sesuai dengan Peraturan Daerah Kota Depok Nomor 07 Tahun 2010 Tentang Pajak Daerah Pasal 58 angka 3 yang menyatakan bahwa Objek Pajak yang tidak dikenakan Pajak Bumi dan Bangunan Perdesaan dan Perkotaan adalah objek pajak yang: Digunakan oleh pemerintah pusat dan daerah untuk penyelenggaraan pemerintah.; Digunakan untuk semata-mata untuk melayani kepentingan um um di bidang ibadah, sosial, kesehatan, pendidikan dan kebudayaan nasional, yang tidak dimaksudkan untuk memperoleh keuntungan; yang dimaksud dengan tidak dimaksudkan untuk memperoleh keuntungan adalah bahwa objek pajak itu diusahakan untuk melayani kepentingan umum, dan nyata-nyata tidak ditujukan untuk mencari keuntungan. Hal ini dapat diketahui antara lain dari anggaran dasar dan anggaran rumah tangga dari yayasan/badan yang bergerak dalam bidang ibadah, sosial, kesehatan, pendidikan, dan kebudayaan nasional tersebut. ; Digunakan untuk kuburan, peninggalan purbakala, atau yang sejenis dengan itu.; Merupakan hutan lindung, hutan suaka alam, hutan wisata, taman nasional, tanah penggembalaan yang dikuasai oleh desa, dan tanah negara yang belum dibebani suatu hak. Termasuk pengertian hutan wisata adalah hutan wisata milik negara sesuai dengan ketentuan peraturan perundang-undangan. ; Digunakan oleh perwakilan diplomatik dan konsulat berdasarkan asas perlakuan timbal balik. ; Digunakan oleh badan atau perwakilan lembaga internasional yang ditetapkan dengan Peraturan Menteri Keuangan.

Subjek dan Wajib Pajak PBB Sektor P2 di Kota Depok sesuai dengan Peraturan Daerah Kota Depok Nomor 07 Tahun 2010 Tentang Pajak Daerah Pasal 59 angka 1 dan 2 adalah: Subjek Pajak Bumi dan Bangunan Perdesaan dan Perkotaan adalah orang pribadi atau badan yang secara nyata mempunyai suatu hak atas bumi dan/atau memperoleh manfaat atas bumi, dan/atau memiliki, menguasai, dan/atau memperoleh manfaat atas bangunan. Wajib Pajak Bumi dan Bangunan Perdesaan dan Perkotaan adalah orang pribadi atau badan yang secara nyata mempunyai suatu hak atas bumi dan/atau memperoleh manfaat atas bumi, dan/atau 
memiliki, menguasai, dan/atau memperoleh manfaat atas bangunan.

\section{Tarif Pajak, Dasar Pengenaan Pajak, Nilai} Jual Objek Pajak Tidak kena Pajak \& Cara Menghitung Pajak

Peraturan Daerah Kota Depok Nomor 07 Tahun 2010 Tentang Pajak Daerah Pasal 61 menyatakan bahwa Tarif Pajak PBB-P2 ditetapkan sebesar : 0,125 \% untuk NJOP dibawah Rp. 1.000.000.000,- (satu milyar rupiah); dan 0,25\% untuk NJOP diatas Rp. 1.000.000.000,- (satu milyar rupiah).

Dasar pengenaan PBB Perdesaan dan Perkotaan adalah Nilai Jual Objek Pajak (NJOP). Peraturan Walikota Depok Nomor 46 Tahun 2013 Pasal 1 angka 16 menyebutkan bahwa Nilai Jual Obyek Pajak, yang selanjutnya disingkat NJOP adalah harga rata-rata yang diperoleh dari transaksi jual beli yang terjadi secara wajar, dan bilamana tidak terdapat transaksi jual beli, Nilai Jual Obyek Pajak ditentukan melalui perbandingan harga dengan obyek lain yang sejenis, atau nilai perolehan baru, atau Nilai Jual Obyek Pajak Pengganti.

Peraturan Daerah Kota Depok Nomor 07 Tahun 2010 Tentang Pajak Daerah Pasal 58 angka 4 menyatakan bahwa NJOPTKP ditetapkan sebesar Rp. 10.000.000,00 (sepuluh juta rupiah) untuk setiap wajib pajak.NJOPTKP merupakan suatu batas NJOP di mana wajib pajak tidak terutang pajak. Maksudnya adalah apabila seorang wajib pajak memiliki objek pajak yang nilainya dibawah NJOPTKP, maka wajib pajak tersebut dibebaskan dari pembayaran pajak. Selain itu, bagi setiap wajib pajak yang memiliki objek pajak yang nilainya melebihi NJOPTKP, maka perhitungan NJOP sebagai dasar perhitungan pajak terutang dilakukan dengan terlebih dahulu mengurangkan NJOP dengan NJOPTKP.

Peraturan Daerah Kota Depok Nomor 07 Tahun 2010 Tentang Pajak Daerah Pasal 62 menyatakan bahwa besaran pokok Pajak PBB$\mathrm{P} 2$ yang terutang dihitung dengan cara mengalikan tarif dengan dasar pengenaan pajak setelah dikurangi Nilai Jual Objek Pajak Tidak Kena Pajak.

Pajak Terutang $=$ Tarif Pajak $\mathrm{x}$ Dasar Pengenaan Pajak

$=$ Tarif Pajak x (NJOP - NJOPTKP $)$

$=$ Tarif Pajak $\mathrm{x}\{(\mathrm{NJOP}$ Bumi + NJOP Bangunan) - NJOPTKP)\}

\section{Permasalahan Pemungutan PBB Sektor P2 di Kota Depok}

Dalam pelaksanaan pemungutan PBB Sektor P2 di Kota Depok ditemukan beberapa permasalahan sebagai berikut : Masih Sedikitnya Tempat Pembayaran PBB-P2; Tingginya Tunggakan Pajak Bumi dan Bangunan (PBB-P2) Terjadinya tunggakan PBB-P2 sebagaimana data pada tabel 4.6 tersebut diatas disebabkan juga karena adanya kesalahan dalam penulisan nama wajib pajak dan luas objek pajak yang tidak sesuai dengan kenyataan yang menyebabkan wajib pajak enggan untuk membayar pajak yang terutang. Rendahnya KeinginanMasyarakat dalam Memenuhi Kewajibannya sebagai Wajib Pajak Bumi dan Bangunan (PBB-P2); Jumlah 
Pegawai yang Tidak Sebanding dengan Jumlah Wajib Pajak;
Menurut Peraturan Daerah Kota Bekasi No. 2 Tahun 2012 Pasal 3 ayat (2) Termasuk dalam pengertian Bangunan adalah :

Tabel 6

\section{Tunggakan PBB-P2 Kota Depok Tahun Anggaran 2012-2014}

\begin{tabular}{|c|c|c|}
\hline No. & Tahun & Tunggakan \\
\hline 1. & 2012 & Rp. 51.027.884.423 \\
\hline 2. & 2013 & Rp. 56.469.643.873 \\
\hline 3. & 2014 & Rp. 56.069.144.164 \\
\hline
\end{tabular}

Sumber : DPPKA Kota Depok, data diolah kembali oleh penulis

Usaha-usaha Peningkatan Penerimaan PBB

Sektor $\mathrm{P}_{2}$ di Kota Depok; Meningkatkan profesionalisme petugas, yaitu dengan cara Meningkatkan operasional pemungutan, melalui penyuluhan atau sosialisasi.

\section{PBB Sektor P2 di Kota Bekasi}

Yang menjadi dasar hukum pengenaan PBB Sektor $\mathrm{P}_{2}$ di Kota Bekasi adalah sebagai berikut : Undang-undang Nomor 28 Tahun 2009 tentang Pajak Daerah dan Retribusi; Peraturan Daerah Kota Bekasi No. 2 Tahun 2012

\section{Objek \& Subjek Pajak PBB Sektor P2 di Kota Bekasi}

Objek PBB P2 diatur dalam Peraturan Daerah Kota Bekasi No.2 Tahun 2012 Pasal 3 ayat (1) dijelaskan, Objek Pajak Bumi dan Bangunan Perdesaan dan Perkotaan atau PBB P2 adalah Bumi dan/atau Bangunan yang dimiliki, dikuasai, dan/atau dimanfaatkan oleh orang pribadi atau badan, kecuali kawasan yang digunakan untuk kegiatan usaha perkebunan, perhutanan, dan pertambangan. jalan lingkungan yang terletak dalam satu kompleks bangunan sepertihotel, pabrik, dan emplasemennya, yang merupakan suatu kesatuandengan kompleks bangunan tersebut. Jalan tol; kolam renang; pagar mewah; tempat olah raga; galangan kapal, dermaga; taman mewah; tempat penampungan/kilang minyak, air dan gas, pipa minyak; dan menara.

Objek Pajak yang tidak dikenakan PBB P2 menurut Peraturan Daerah Kota Bekasi Pasal 3 ayat (3) adalah objek pajak yang: digunakan oleh Pemerintah, dan Daerah untuk penyelenggaraan pemerintahan; digunakan semata-mata untuk melayani kepentingan umum di bidang ibadah, kesehatan, sosial, pendidikan dan kebudayaan nasional, yangtidak dimaksudkan untuk memperoleh keuntungan; digunakan untuk kuburan, peninggalan purbakala, atau yang sejenis dengan itu;merupakan hutan lindung, hutan suaka alam, hutan wisata, taman nasional, tanah penggembalaan yang dikuasai oleh desa, dan tanah negara yang belum dibebani suatu hak; digunakan oleh perwakilan 


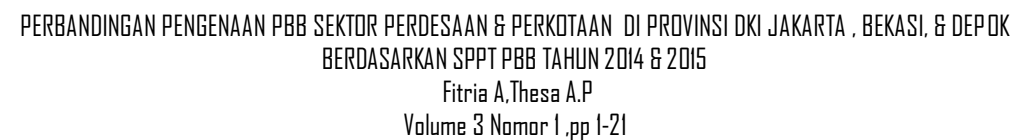

diplomatik dan konsulat berdasarkan asas perlakuan timbal balik; dan digunakan oleh badan atau perwakilan lembaga internasional yang ditetapkan dengan Peraturan Menteri Keuangan.

Adapun Subjek Pajak $\mathrm{PBB} \mathrm{P}_{2}$ diatur dalam Pasal 4 Ayat (1) Peratuan Daerah Kota Bekasi No.2 Tahun 2012 yang dinyatakan bahwa Subjek $\mathrm{PBB} \mathrm{P}_{2}$ adalah orang pribadi atau badan yang secara nyata : mempunyai suatu hak atas Bumi dan/atau memperoleh manfaat atas Bumi, dan/atau; memiliki, menguasai, dan/atau memperoleh manfaat atas Bangunan. Pengertian Wajib Pajak menurut Peraturan Daerah Kota Bekasi No.2 Tahun 2012 Pasal 4 Ayat (2) di jelaskan bahwa, Wajib PajakPBB $\mathrm{P} 2$ adalah orang pribadi atau badan yang secara nyata mempunyai suatu hak atas Bumidan/atau memperoleh manfaat atas Bumi, dan/atau memiliki, menguasai, dan/atau memperoleh manfaat atas Bangunan. Pada dasarnya yang menjadi subjek pajak sekaligus menjadi Wajib Pajak atau dikenakan kewajiban membayar pajak adalah orang atau badan yang mempunyai hak atau memperoleh manfaat atas objek tersebut. Namun apabila dalam hal objek pajak belum jelas diketahui siapa Wajib Pajaknya, maka Kepala Dinas Pendapatan Daerah Kota Bekasi dapat menentukan Wajib Pajaknya atas Objek Pajak tersebut. Pengertian Wajib Pajak menurut Peraturan Daerah Kota Bekasi No.2 Tahun 2012 Pasal 4 Ayat (2) di jelaskan bahwa, Wajib PajakPBB $\mathrm{P}_{2}$ adalah orang pribadi atau badan yang secara nyata mempunyai suatu hak atas Bumidan/atau memperoleh manfaat atas Bumi, dan/atau memiliki, menguasai, dan/atau memperoleh manfaat atas Bangunan.

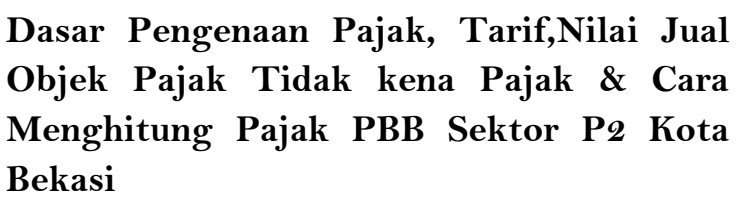

Dasar Pengenaan PBB P2 adalah Nilai Jual Objek Pajak (NJOP), seperti yang diatur dalam Peraturan Daerah Kota Bekasi No.2 Tahun 2012 Pasal 6 Ayat (2).Besarnya NJOP sebagaimana dimaksud pada ayat (1) ditetapkan setiap 3 (tiga) tahun, kecuali untuk objek pajak tertentu dapat ditetapkan setiap tahun sesuai dengan perkembangan wilayahnya.

Berdasarkan Peraturan Daerah Kota Bekasi No.12 Tahun 2012 Pasal 5 Tarif PBB P2 ditetapkan sebagai berikut : sebesar 0,1 \% (nol koma satu persen) untuk NJOP sampai dengan Rp. 500.000.000,00 (lima ratus juta rupiah); sebesar 0,15\% (nol koma lima belas persen) untuk NJOP di atas Rp. 500.000.000,00 (lima ratus juta rupiah)

sampai dengan Rp. 1.000.000.000,00 (satu milyar rupiah); sebesar 0,25\% (nol koma dua lima persen) untuk NJOP di atas Rp.1.000.000.000,00 (satu milyar rupiah). Penghitungan PBB yang terhutang, didapatkan berdasarkan besarnya Nilai Jual Objek Pajak (NJOP) dikurangi Nilai Jual Objek Pajak Tidak Kena Pajak (NJOPTKP) yang bertujuan memberikan keringanan kepada masyarakat berpenghasilan rendah.NJOPTKP ini diberikan untuk setiap Wajib Pajak namun apabila Wajib Pajak mempunyai lebih dari satu Objek Pajak maka 
yang mendapatkan NJOPK hanya satu objek, yaitu yang mempunyai nilai tertinggi.

Besarnya NJOPTKP menurut Pasal 7 ayat (1) Peratuan Daerah Kota Bekasi No.2 Tahun 2012, besarnya nilai NJOPTKP ditetapkan sebesar Rp.10.000.000 untuk setiap Wajib Pajak.

\section{Permasalahan Pemungutan PBB Sektor P2 di Kota Bekasi}

Kurangnya kesadaran Wajib Pajak akan kewajiban perpajakannya. Wajib Pajak yang suka menunda- nunda pembayaran untuk melunasi $\mathrm{PBB} \mathrm{P} 2$ pada saat tanggal jatuh tempo.; Wajib pajak menolak SPPT karena salah tulis nama dan alamat.;Wajib pajak merasa malas membayar PBB P2 karena tidak mendapatkan kontraprestasi secara langsung dari pemerintah.; Kondisi ekonomi Wajib Pajak, terkadang dengan kondisi ekonomi yang kurang stabil, dapat menyebabkan Wajib Pajak kurang lancar dalam memenuhi kewajiban perpajakannya. ; Banyak objek pajak yang berganti kepemilikan sedangkan SPPT masih menggunakan nama yang lama.

\section{Kendala- kendala yang dihadapi fiskus :}

Sumber daya manusia, seperti sulit menentukan NJOP (Nilai Jual Objek Pajak). pelaksanaan penghitungan NJOP di Kota Bekasi pada prakteknya dilaksanakan setiap 3 tahun sekali. Hal ini dikarenakan adanya keterbatasan sumber daya manusia dan financial, mengingat kurang seimbangnya jumlah pegawai dengan luas wilayah Kota Bekasi. ; SPPT ganda, masalah ini lebih bersifat teknis yang biasanya dapat diakibatkan karena pencetakan atau kesalahan dari pihak fiskus.;Sistem administrasi masih kurang baik.

\section{Upaya Untuk Mengatasi Permasalahan dalam Pemungutan PBB Sektor P2 Kota} Bekasi

Dalam hal pembayaran, mengadakan POS PBB (Payment On Line System) sistem ini merupakan sistem PBB On Line ; Untuk lebih memberikan pelayanan kepada Wajib Pajak, dapat dibuka pelayanan melalui telpon, Wajib Pajak dapat mengetahui mengenai informasi mengenai pengajuan keberatan, pembetulan SPPT, informasi tagihan pajak, dan informasi mengenai status pembayaran PBB.;Upaya untuk mengatasi kesulitan penentuan NJOP (Nilai Jual Objek Pajak) Dispenda Kota bekasi mencari sebanyak mungkin informasi sebagai referensi untuk menentukan NJOP.;Untuk mengatasi kendala sumber daya manusia, Dispenda Kota Bekasi melakukan perekrutan karyawan dengan mempekerjakan tenaga honorer dan menggunakan tenaga pelajar yang sedang melakukan praktek kerja lapangan untuk membantu pekerjaan karyawan seperti memasukan data- data mengenai Wajib Pajak. Upaya untuk mengatasi kendala adanya SPPT ganda, Dispenda Kota Bekasi melakukan pendataan yang lebih akurat. Upaya untuk mengatasi sistem administrasi yang kurang baik, Dispenda Kota Bekasi melakukan perbaikan sistem teknologi dan informasi atas sistem yang digunakan sebagai alat administrasi perpajakan Upaya- upaya untuk mengatasi kendala yang berasal dari Wajib Pajak, antara 
lain: Dispenda Kota Bekasi senantiasa memberikan penyuluhan antara lainPenyuluhan yang lebih aktif seperti opsir (oprasi sisir), Penyebaran informasi biasanya melalui media elektronik seperti radio daerah setempat, media cetak sepeti pamflet atau spanduk, serta koordinasi dengan aparat kelurahan setempat. Untuk mengatasi Wajib Pajak yang suka menunda- nunda pembayaran atau melunasi pada saat jatuh tempo. Dispenda Kota Bekasi akan memberikan informasi lebih awal kepada masyarakat, Dispenda Kota Bekasi pun sedang merencanakan pemanfaatanpenggunaan smartphone atau aplikasi android, untuk memudahkan masyarakat Kota Bekasi untuk mengetahui informasi mengenai jatuh tempo pembayaran pajak, melaporkan properti, mengatahui tunggakan dengan aplikasi tersebut. Diharapkan dengan aplikasi ini dapat memudahkan masyarakat untuk menerima informasi. Upaya untuk mengatasi kesalahan penulisan nama dan alamat Wajib Pajak, aparat melakukan pendatan dan pengecekan konfirmasi ulang untuk memastikan kebenaran data Wajib Pajak. pengecekan dapat dilakukan dengan menelpon Wajib Pajak atau dengan mendatangi kediaman Wajib Pajak. Pengecekan juga dapat dilakukan dengan memisahkan fungsi pengecekan dengan fungsi verifikasi. Dengan cara ini penulisan nama dan alamat dapat di minimalisir. Untuk mengatasi kendala kesulitan ekonomi Wajib Pajak. Dispenda hanya sebatas memberikan peringatan dan sanksi apabila Wajib Pajak tidak melunasi kewajiban perpajakannya. Selain itu, Dispenda
Kota Bekasi juga memberikan kebijakan kepada Wajib Pajak untuk membayar dengan cara mengangsur atau meminta keringanan dari seluruh kewajiban yang harus dibayarkan. Dengan cara ini pula, penerimaan $\mathrm{PBB} \quad \mathrm{P}_{2}$ akan lebih berkesinambungan disamping memberikan kemudahan bagi Wajib Pajaknya.

\section{Perbandingan Pengenaan PBB Sektor Pa} Provinsi DKI Jakarta, Depok, \& Bekasi

Pemungutan $\mathrm{PBB}$ Sektor $\mathrm{P}_{2}$ yang pengenaannya didasarkan pada Peraturan Daerah masing-masing, dapat berbeda-beda antara satu daerah dengan daerah yang lain. Hal ini disebabkan karena pengenaan PBB Sektor $\mathrm{P}_{2}$ tersebut diserahkan kewenangannya kepada Pemerintah Daerah masing-masing. Penentuan besarnya Nilai Jual Objek Pajak (NJOP), Nilai Jual Objek Pajak Tidak Kena Pajak (NJOPTKP), tarif pajak, dan sebagainya sepenuhnya diatur oleh Pemerintah Daerah masing-masing yang dituangkan dalam bentuk Peraturan Daerah.

Dari uraian yang telah dijabarkan pada bagian-bagian sebelumnya, dapat dilihat bahwa dalam pelaksanaan pengenaan PBB Sektor $\mathrm{P} 2$ di provinsi DKI Jakarta, Depok, dan Bekasi, terdapat perbedaan dari segi penetapan dasar pengenaan pajak, tarif pajak, serta besarnya NJOPTKP yang diberikan kepada setiap Wajib Pajak. Berikut adalah ikhtisar perbedaan tersebut :

\section{Dasar Hukum}

DKI Jakarta

a. UU RI No 28 Tahun 2009 tentangPajak 
Daerah danRetribusi Daerah

b. Perda No 6 Tahun 2010 tentang Ketentuan Umum Pajak Daerah

c. Perda No 16 Tahun 2011 Tentang Pajak Bumi dan Bangunan (berlaku mulai tanggal 1-1-2013)

d. Peraturan Gubernur No 175 Tahun 2013 Tentang Klasifikasi dan Penetapan Nilai Jual Objek Pajak dan Dasar Pengenaan PBB Pedesaan dan Perkotaan

e. Peraturan Gubernur No.263 Tahun 2014 Tentang Klasifikasi dan Penetapan Nilai Jual Objek Pajak dan Dasar Pengenaan PBB Pedesaan dan Perkotaan

Depok

1. Undang-undang Nomor 28 Tahun 2009 tentangPajak Daerah dan Retribusi Daerah.

2. Peraturan Daerah Kota Depok Nomor 07 Tahun 2010 tentang Pajak Daerah.

3. Peraturan Walikota Depok Nomor 45 Tahun 2011 tentang tata cara pemungutan Pajak Bumi dan Bangunan Perdesaan dan Perkotaan di Kota Depok sebagaimana telah diubah terakhir dengan Peraturan Walikota Depok Nomor 46 Tahun 2013

Bekasi

a. Undang-undang Nomor 28 Tahun 2009 tentang Pajak Daerah dan Retribusi

b. Peraturan Daerah Kota Bekasi No. 2 Tahun 2012

\section{Dasar Pengenaan Pajak}

DKI Jakarta

NJOP, ditetapkan setiap 1 (satu) tahun
Depok

NJOP, ditetapkan setiap 3 (satu) tahun

Bekasi

NJOP, ditetapkan setiap 3 (satu) tahun

\section{Tarif Pajak}

DKI Jakarta

a. Tarif $0,01 \%$ (nol koma nol satu persen) untuk Nilai Jual Objek Pajak Tanah dan/atau Bangunan kurang dari Rp.200.000.000,- (dua ratus juta rupiah);

b. Tarif $0,1 \%$ (nol koma satu persen) untuk Nilai Jual Objek Pajak Tanah dan/atau Bangunan Rp.200.000.000,- (dua ratus juta rupiah) sampai dengan kurang dari Rp.2.000.000.000. (dua miliar rupiah);

c. Tarif 0,2\% (nol koma dua persen) untuk Nilai Jual Objek Pajak Tanah dan/atau Bangunan Rp.2.000.000.000.- (dua miliar rupiah) sampai dengan kurang dari Rp.10.000.000.000.- (sepuluh miliar rupiah);

d. Tarif 0,3\% (nol koma tiga persen) untuk Nilai Jual Objek Pajak Tanah dan/atau Bangunan Rp.10.000.000.000,- (sepuluh miliar rupiah) atau lebih.

Depok

a. $0,125 \%$ untuk NJOP dibawah Rp. 1.000.000.000,- (satu milyar rupiah);dan

b. $0,25 \%$ untuk NJOP diatas Rp. 1.000.000.000,- (satu milyar rupiah).

Bekasi

a. sebesar 0,1\% (nol koma satu persen) untuk NJOP sampai dengan Rp. 500.000.000,00 
(lima ratus juta rupiah);

b. sebesar 0,15\% (nol koma lima belas persen) untuk NJOP di atas Rp. 500.000.000,00 (lima ratus juta rupiah) sampai denganRp. 1.000.000.000,00 (satu milyar rupiah);

c. sebesar 0,25\% (nol koma dua lima persen) untuk NJOP di atas Rp.1.000.000.000,00 (satu milyar rupiah)

\section{NJOPTKP}

DKI Jakarta

Rp. 15.000.000,-

Depok

Rp.10.000.000,-

Bekasi

Rp.10.000.000,-

\section{SIMPULAN}

Dari pembahasan yang telah dijabarkan pada bagian sebelumnya, dapat ditarik beberapa kesimpulan sebagai berikut : Pengenaan PBB Sektor $\mathrm{P}_{2}$ di Provinsi DKI Jakarta, Bekasi, dan Depok telah dilaksanakan sesuai dengan ketentuan dalam Peraturan Daerah masingmasing dengan tetap mengacu pada ketentuan UU No.28 Tahun 2009 tentang Pajak Daerah \& Retribusi Daerah. Walaupun ketentuan pengenaan $\mathrm{PBB}$ Sektor $\mathrm{P} 2$ di Provinsi DKI Jakarta, Depok, dan Bekasi berbeda-beda dari segi tarif pajak, besarnya NJOPTKP, serta penentuan besarnya NJOP, tetapi tidak bertentangan dengan ketentuan yang diatur dalam UU No.28 Tahun 2009 tentang Pajak Daerah \& Retribusi Daerah.
Sebagai contoh, besarnya tarif $\mathrm{PBB}$ Sektor $\mathrm{P} 2$ di ketiga daerah tersebut tidak ada yang melebihi batas tarif maksimal, yaitu 0,3\%. Besarnya NJOPTKP juga tidak ada yang di bawah batas minimal yakni sebesar Rp.10.000.000,- untuk setiap Wajib Pajak.; Besarnya NJOP di Provinsi DKI Jakarta lebih tinggi dan lebih beragam dibandingkan dengan NJOP di kota Depok dan Bekasi. Penentuan besarnya NJOP di Provinsi DKI Jakarta juga ditetapkan lebih sering daripada di kota Depok dan Bekasi, yakni setiap satu tahun. Hal ini disebabkan karena nilai tanah dan bangunan di Provinsi DKI Jakarta lebih cepat naik daripada di Depok dan Bekasi.; Dalam pelaksanaan pemungutan PBB Sektor P2 terutama di Kota Depok dan Bekasi, ditemui adanya beberapa kendala seperti keterbatasan fasilitas untuk memenuhi kewajiban perpajakan dan juga fasilitas untuk melakukan pemungutan pajak, serta keterbatasan sumber daya manusia yang tersedia di Dispenda masing-masing. Selain itu, masih rendahnya kesadaran Wajib Pajak untuk memenuhi kewajiban perpajakannya juga menjadi kendala dalam pelaksanaan pemungutan $\mathrm{PBB}$ Sektor $\mathrm{P} 2$; Pemerintah Daerah masing-masing terus berupaya untuk mengatasi kendala-kendala yang dihadapi dalam pelaksanaan pemungutan PBB Sektor $\mathrm{P} 2$, antara lain dalam bentuk pemberian penyuluhan, memberi kemudahan dari segi administrasi dan merekrut tenaga pelaksanaan PBB Sektor $\mathrm{P}_{2}$. 


\section{DAFTAR PUSTAKA}

Darwin, 2013. Pajak Bumi dan Bangunan dalam Tataran Praktis (Edisi 2), Jakarta: Mitra Wacana Media.

Kurniawan,Panca dan Agus Purwanto, 2004. Pajak Daerah dan Retribusi Daerah di Indonesia, Malang: Bayumedia.

Lutfi, Ahmad DKK., Devolusi Pajak Bumi dan Bangunan: Tantangan dan Peluang Penguatan Taxing Capacity untuk Mendorong Daya Saing Daerah. Jakarta: Penerbit Universitas Indonesia, 2013.

Slamet, Soelarno, Pajak Daerah dan Retribusi Daerah. Jakarta: STIA LAN Press, 1999

Yani, Ahmad, Hubungan Keuangan Antara Pemerintah Pusat dan Daerah di Indonesia. Jakarta: PT Rajagrafindo Persada, 2002

Fitriana, Dian, Kepatuhan Wajib Pajak Tahun 2014 di Dinas $\quad$ Pendapatan Kota Bekasi. Depok: Universitas Indonesia, 2015

Wahyono, Tri, 2015.Efektivitas Pemungutan Pajak Bumi dan Bangunan (PBB- $\quad$ P2) Pada DPPKA Kota Depok. Depok: Universitas Indonesia

Republik Indonesia, Undang-undang Nomor 28 Tahun 2009 tentang Pajak Daerah \& Retribusi Daerah, Jakarta, 2009

Daerah Khusus Ibukota Jakarta, Peraturan Daerah No 6 Tahun 2010 tentang Ketentuan Umum Pajak Daerah, Jakarta, 2010 Peraturan Daerah No 16 Tahun 2011 Tentang Pajak Bumi dan Bangunan, Jakarta, 2011

Kota Depok, Peraturan Daerah Kota Depok Nomor 07 Tahun 2010 tentang Pajak Daerah, Depok, 2010 Kota Bekasi, Peraturan Daerah Kota Bekasi No. 2 Tahun 2012 tentang $\quad$ Pajak Daerah, Bekasi, 2012 Gubernur DKI Jakarta, Peraturan Gubernur No 175 Tahun 2013 Tentang Klasifikasi dan Penetapan Nilai Jual Objek Pajak dan DasarPengenaan PBB Pedesaan dan Perkotaan, Jakarta, 2013 , Peraturan Gubernur No.263 Tahun 2014. Tentang Klasifikasi dan Penetapan Nilai

Jual Objek Pajak dan Dasar Pengenaan PBB Pedesaan dan Perkotaan, Jakarta, 2014

Walikota Depok, Peraturan Walikota Depok Nomor 45 Tahun 2011 tentang tata cara pemungutan Pajak Bumi dan Bangunan Perdesaan dan Perkotaan di Kota Depok, Depok, 2011 Peraturan Walikota Depok Nomor 46 Tahun 2013tentang tata cara pemungutan Pajak Bumi dan Bangunan Perdesaan dan Perkotaan di Kota Depok, Depok, 2013 